\title{
Odysseus, metodologia ja maailman yltäkylläisyys
}

Sari Husan raikkaat ja oivaltavat ajatukset (Aikuiskasvatus 4/95) väitöskirjastani vaativat jatkamaan keskustelua. Kommentaarini tahtoo painottaa argumentoinnin tarpeellisuutta suomalaisissa tiedekeskusteluissa ja korostaa oivaltavien kirja-arvioiden yleistä arvoa keskustelun avaajina.

Sari Husa luonnehtii tutkielmaani omaleimaiseksi. Omaleimaisuus on tietenkin suhteellinen asia ja riippuu pitkälti siitä, mitä sanalla 'omaleimaisuus' kulloinkin tarkoitetaan. Omaleimaisuus saa merkityksensä ei niinkään puheena olevasta kohteesta kuin siitä kontekstista, jonka muodostavat muut kasvatustieteelliset väitöskirjat. jos niiden antamat puitteet näyttävät toistavan samaa ja muuttumatonta osaamista esimerkiksi metodologisesti ja menetelmällisesti, voi oman leiman laskea jopa hyveeksi.

\section{Odysseus ja harharetket}

Tutkielmani tarkastusta seuranneissa juhlallisuuksissa asennettani kuvattiin mm. viittauksella Odysseukseen ja hänen retkiinsä. Odysseuksen retkiin kuuluva määre 'harha' jätettiin ilmeisesti häveliäisyyssyistä sanomatta.

En kuitenkaan ole lainkaan varma, etteikö Odysseuksen asennetta tarvittaisi muulloinkin kuin vain aikoina, joita yhtenä muiden joukossa nimitän metodologisiksi murroskausiksi. Vähintäin tällaisina kausina etsiminen, harhautuminen, kiistat, kiihko, epätoivo ja epävarmuus tieteellisen tutkimuksen tiestä, siis metodista, ja tien suunnasta, tieteellisen tutkimuksen tavoitteista, kuuluvat, tai ainakin niiden tulisi kuulua, yhteiskuntatieteilijän sekä ulkoiseen että sisäiseen peruskokemukseen. Voidaan kysyä, miksi tällaiset sieluntilat sitten ovat tärkeitä, ja antaa kysymykseen useita, eri perustein ja eri lähtökohdista valittuja vastauksia.

»Kommentaari kysyy diskurssilta, mitä se sanoo ja mitä sen oli tarkoitus sanoa.

Se pyrkii tuomaan esiin puheen syvemmän merkityksen - lausumalla se, mitä on sanottu, pyritään toisin sanoen ilmaisemaan uudelleen se, mitä ei koskaan sanottu. "

- Michel Foucault, Klinikan synty

Ajattelun historia tuntee kaikilta aikakausilta ihmisiä, joita on ohjannut peräänantamaton halu uudistaa ja uudelleen luoda ensisijassa itsensä tiedon ja sivistyksen kautta. Esimerkki lähimenneisyydestä on Michel Foucault, joka puhuu ajattelun askeesista tarkoittaen sisäistä motivaatiota ja paloa siihen niitä tekee. Tällöin toiminnan ulkoiset yllykkeet ovat vähemmän tärkeitä kuin se itseen kohdistuva transformaatio jonka kokee tärkeäksi. Ajattelun askeesi ei tarkoita itsekorostusta, vaan ennen kaikkea sitä, että muiden on mahdollista tunnistaa tämä ajattelutapa, ja pyrkiä omalla kohdallaan toteuttamaan samankaltaista tietä ja ottaa opikseen. Ajattelun askeesi on siis syvällisessä merkityksessä pedagoginen tapa toimia, koska se asettaa sisäisesti perustellun lähtökohdan toiminnan perustaksi.

\section{Ensin arvauksia, sitten kumouksia}

Tutkielmani nousee liberaalin ajattelutavan juuristosta, jos liberaalilla viitataan avauksiin, arvauksiin ja keksintöihin kiinnostavina ja tärkeinä tieteellisen työn tunnusmerkkeinä. Ehkä tutkijoita todellakin on kahteen junaan: niitä, jotka inventoivat tieteenalansa peruskysymyksiä 
ajattelun ja empirian teitä esittämällä jyrkiltäkin vaikuttavia arvauksia, ja niitä, jotka yhtä kriittisesti osoittavat inventaariomme alustaviksi, mahoiksi ja virheellisiksi. Oma lukunsa on kysymys siitä, voidaanko ihmistieteissä, jossa tutkimuskohteina ovat ajallisesti ja paikallisesti alati muuttuvaiset sosiaaliset käytännöt, olettaakaan eksaktia tosiasiatietoa, johon edellä esitetty arvausten ja kumousten vuoroleikki viittaa vai onko kaava otettava ihmistieteissä pelkkänä tutkimusta ohjaavana metaforana.

Toivottavaa joka tapauksessa on, että tutkimusta yllyttää eteenpäin idea, jota voisi kutsua alusta ajattelemisen periaatteeksi. Että tuntisimme tehtäväksemme selvittää tutkimuskohteemme aina uutena emmekä alistuisi jossain muualla jo valmiiksi esitetyille tai ensimmäisenä mieleentuleville näkemyksille. Etsiminen ei kuulu vain filosofiaan, vaan on se ominaista tieteessä yleensä.

\section{Introspektio vs. kirjoitustapa}

Itsetutkiskelu, itsensä tunteminen ja itsevaarinotto, on täysin välttämätöntä kaikille yhteiskunnan tutkijoille ja tutkijoille ylipäätään; se ei kosketa vain laadullista metodiikkaa, jossa tutkijan osuus ja tästä osuudesta raportointi on nostettu näkyvästi esiin tutkimuksen luotettavuuden koettimena. Toisaalta kysymys on paljon muodollisemmasta ja retorisemmasta asiasta, nimittäin siitä, millaisen kirjoittamistavan kirjoittaja on valinnut; itse olen valinnut tavan, jossa käytän yksikön ensimmäistä persoonaa. Tämä ei historiallisesti (tästä Descartes-vertailu) ja suhdanteittain muuttuvana seikkana saa hämärtää sitä tosiasiaa, että riippumatta sijamuodoista, tutkimuksen kuin tutkimuksen kirjoittaa aina joku toimija, subjekti, agentti.

Arviossa viitataan introspektioon liittyen myös käyttämääni typologisoinnin menetelmään. jos edellä esitettyyn nojaten oletetaan, että introspektio, tai paremminkin omien tekstien uudelleen lukeminen, ei olisi ongelma, voitaisiin pohtia myös arviossa esitetyn 'positivismi'-teesin relevanssia. Ensinnäkin, laadullisten menetelmien luokittelusta ei tahdo viitata niiden kohteiden, siis indeterministisen inhimillisen toiminnan, yksinkertaistavaan luokitteluun. Tässä on selkeä ero: tutkia ja ontologisoida ihmistä tutkimuskohteena tai tutkia ja luokitella ihmisen tutkimiseen käytettyjä empiirisiä ja käsitteellisiä välineitä. Toiseksi, metodologinen typologiani vastaa nähdäkseni sitä, mistä Perttu Alasuutari puhuu laadullisen tutkimuksen yleistämisen yhteydessä havaintojen pelkistämisestä kirjassaan Laadullinen tutkimus (1993, s. 197): "Toisinaan typologia ... voi viitata laajempaan kokonaisuuteen kuin vain siihen historiallisesti ja paikallisesti määriteltyyn kulttuuriseen rakenteeseen, johon aineiston tapaukset suhteutetaan ja sitä kautta ikään kuin yleistetään." Tämä antaa mahdollisuuden aivan järkevästi soveltaa ensikädessä omista kirjoituksistani rakentamaani typologiaa myös muihin tapauksiin muissa yhteyksissä.

Kaikille teoksille, olivat ne sitten tekstejä, sävellyksiä, kuvia tai esteettisiä esineitä, on luontaista, että ne alkavat elää omaa elämäänsä varsinaisen luomisensa jälkeen. Ts. ne alkavat irtautua tekijäintentioista (intentio auctoris) kohti tulkitsijaintentioita (intentio lectoris). Tästä mielessä tutkielmani tekstit ovat omalakisia ja materiaalisia kulttuurituotteita, objektiivista todellisuutta, siis irronneita siitä intentoivasta tietoisuudesta, siitä subjektiivisesta, joka ne joskus tuotti, enkä tästä kulmasta näe periaatteellista eroa tutkivan katseen kohdistamisessa omiin tai muiden teksteihin. Tutkimuksen tie on tässä mielessä sama kriittisen ajattelun tie.

Symbolisen interaktionismin piirissä ollaan käyty kovaakin kiistaa etnografisen elämäkerran metodista: siitä, että tutkija ottaa itsensä mukaan tutkimistarinaansa sen keskeisenä hahmona ja kirjoittaa auki kulkemaansa polkua välillä hyvinkin persoonallisella tavalla tavoitellen jopa novellin tai romaanin tyyliä. 
Näiden kirjoitustyylien juuret juontavat luonnollisesti antropologisiin matkakertomuksiin ja kuulokuviin kaukaisilta mailta. Tässä mielessä valitsemani kirjoituskäytäntö, yrittämättäkään olla proosallinen, ei ole uusi eikä ihmeellinen. Suomessakin J. P Roosin juhlakirja Kerro vain totuus (1995) antaa viitteitä siitä, että jokaisessa yhteiskuntatieteilijässä asuu pieni kirjailija. Sitä, millaisia ongelmia tutkijan kirjailijapyrkimyksestä voi syntyä, olen lyhyesti pohtinut J. Eskolan, J. Mäkelän ja J. Suorannan toimittamassa antologiassa Ihmistieteiden 1990-luvun metodologiaa etsimässä (1995, 140-142).

Kysymys siitä, missä kulkee kirjailijan ja tieteilijän ero, ja mikä on tämän eron merkitys, on tietenkin yhtä vaikea kuin keskeinenkin metodologinen rajanvetokysymys. Tutkielmaani lukemalla (erityisesti sen 5. lukua) saa yhden, Richard Rortyn ajatteluun nojaavan vastauksen: kumpaisetkin inhimillisen toimeliaisuuden muodot, yhtä lailla proosa- ja yhteiskuntatiedekirjallisuus, kuin matematiikka ja runous, pyrkivät osaltaan hahmottamaan maailmaa ja sovittautumaan siihen.

On myös helppo nähdä, mitkä maailmaan sovittautumisen periaatteet ovat tuotteliaita ja vaikuttavia, mitkä taas eivät. Kuten tunnettua, runoilla tietysti kaadetaan valtakuntia ja valloitetaan sydämiä. Nykyinen teknologinen todellisuuskuva opettaa yhtä vakuuttavasti, että matematiikan edistysaskeleisiin perustuvilla käytännöillä särjetään kohta koko maailma. Rajanvedoista ja niiden merkityksistä olisi siis syytä puhua syvemmin. Syvempi puhuminen on myös merkki aikakaudesta: niin kuin perhosen siivenisku toisella puolella maailmaa voi synnyttää turbulenssin meillä, samoin yhteiskunnalliset ratkaisut eivät enää ole paikallisia, vaan nimenomaan vaativat yleisempää huomiota.

Opinnäytetyöt eivät poikkea muista tutkielmista tai yleisemmin ajateltuna muistakaan kirjallisista töistä siinä, että niissä ei paljasteta eikä kirjoiteta auki kaikkia kirjoittamista ohjaavia ajatuksia, vaikka tällaista voisi odottaakin nimenomaan tieteellisiltä töiltä. Tähän on ajateltavissa ainakin kaksi syystä. Ensinnäkin tieteellisen kirjoittamisen koodit sanelevat väkevästi niitä muotoja, joilla tutkimuksia kirjoitetaan. jonkin genren olemassaolo edellyttää tavan ja mallin. Toisaalta on inhimillistä, ettei kaikkea sittenkään tule kirjoittaessa ajateltua, jotain jää aina sanomatta.

Tämä unohdus voi olla juuri siinä kohdassa, joka koskettaa tutkielman varsinaista ydintä, ja tulee paljastetuksi vasta ajan antaessa tarvittavaa etäisyyttä tutkielman tekstin ja sen tekijän - tässä kohdassa - selkiintyneiden ajatusten välille.

\section{Maailman yltäkylläisyys}

Tutkielmani läpikäyvä kysymys, jonka ympärille muut erityiskysymykset kiertyvät, koskee yhteiskuntatieteilijän paikkaa ja olemista (context and being) sosiaalisessa todellisuudessa, proosallisemmin ilmaistuna, elämistä ja toimimista (tekstejä lukien ja kirjoittaen) tässä ihmisten maailmassa. Tähän teemaan voidaan nähdäkseni kytkeä valtaosa tutkielmassani esille nousevista erityiskysymyksistä.

Sikäli mikäli kirjoitustapani ja sitä myöten tutkielmani kokonaisuuden osat onnistuvat hälventämään yhteiskuntatieteellisen tutkimuksen objektivistisia harharetkiä tai vaikkapa vain problematisoimaan sitä yhteiskuntatieteellisen tutkimuksen intersemioottisen kietoutuneisuuden ja tämän asettaman henkilökohtaisen ja sosiaalisen vastuun tiedostamisen suunnasta, koen onnistuneeni tehtävässäni. Yhteiskuntatieteissä, kun kohteena ovat ihmisen toiminnan lukuisuudet, on vaikeaa asettaa selkeitä ja yksisuuntaisia kysymyksiä, saati sitten yrittää vastata niihin johdonmukaisesti ja ytimekkäästi. Metodologisessa työssä on vaarana, että asiat kiertyvät itseensä ja puhuvat kieltä, joka aukeaa vain harvalle. Kuitenkin tätä vaaraa voi välttää ymmärtämällä niitä 
yhteyksiä, jotka ympäröivät metodologiaa ja menetelmäpohdintoja. Tärkein yhteys on yhteiskuntatieteellisen tutkimuksen suhteellistaminen muuhun yhteiskunnalliseen puheeseen ja yhteiskuntapuheen voimavirtojen analyysiin.

Yksi suosikkini, tieteenfilosofi Paul Feyerabend (1924-1994), oli esimerkki ajattelijasta, joka kirjaimellisesti viimeiseen hengenvetoon puolusti sitä moninaisuutta, joka meissä on, ja jonka tutkimus parhaimmillaan esittää. Hän kykeni vastustamaan houkutusta langeta helppoihin kysymyksiin ja helppoihin yksinkertaistaviin vastauksiin. Hän myös osoitti työssään sen, kuinka tiede tunnistaa yhden osan maailmaa, toisten jäädessä vääjäämättä tunnistumatta. Hän ymmärsi maan olevan tällä tavalla yltäkylläinen.

Juha Suoranta 